\title{
Catalytic properties of cellulases and hemicellulases produced by Lichtheimia ramosa: Potential for sugarcane bagasse saccharification
}

\author{
Nayara Fernanda Lisboa Garcia ${ }^{\mathrm{a}}$, Flávia Regina da Silva Santos ${ }^{\mathrm{a}}$, Daniela Alonso Bocchini ${ }^{\mathrm{b}}$, \\ Marcelo Fossa da Paz ${ }^{\mathrm{a}}$, Gustavo Graciano Fonseca ${ }^{\mathrm{c}}$, Rodrigo Simões Ribeiro Leite, ${ }^{\mathrm{a}, *}$ \\ ${ }^{a}$ Laboratory of Enzymology and Fermentation Processes, Faculty of Biological and Environmental Sciences, Federal University of Grande Dourados (FCBA/UFGD), \\ Dourados, MS, Brazil \\ ${ }^{\mathrm{b}}$ Laboratory of Microbial Enzymes, São Paulo State University - UNESP/IQ, Araraquara, SP, Brazil \\ ${ }^{\mathrm{c}}$ Laboratory of Bioengineering, Faculty of Biological and Environmental Sciences, Federal University of Grande Dourados (FCBA/UFGD), Dourados, MS, Brazil
}

\section{A R T I C L E I N F O}

\section{Keywords:}

Cellulolytic and hemicellulolytic complex

Solid-state fermentation

Saccharification of vegetable biomass

Enzymatic saccharification

\begin{abstract}
A B S T R A C T
The use of microbial enzyme cocktails for the conversion of polysaccharides of plant origin into fermentable sugars is a global trend. The objectives of this study were to optimize the production of cellulases and hemicellulases by the fungus Lichtheimia ramosa, evaluate the catalytic properties of the produced enzymes, and apply these biocatalysts in the saccharification of sugarcane bagasse. The production of carboxymethylcellulase (CMCase), $\beta$-glucosidase, xylanase, and $\beta$-xylosidase by $L$. ramosa were $168.1 \pm 2.2,270.4 \pm 8.9,34 \pm 0.8$, and $199.2 \pm 2.6 \mathrm{U} / \mathrm{g}$ of dry substrate, respectively. The optimum $\mathrm{pH}$ for the activity of the enzymes ranged between 4.5 and 5.5, and the optimum temperature varied between $55^{\circ} \mathrm{C}$ and $65{ }^{\circ} \mathrm{C}$. The enzymes were stable within a wide range of $\mathrm{pH}$, and approximately $95 \%$ of their original activity was preserved when incubated for $1 \mathrm{~h}$ at $55^{\circ} \mathrm{C}$. The half-lives $\left(t_{1 / 2}\right)$ of CMCase, $\beta$-glucosidase, xylanase, and $\beta$-xylosidase were $68,59,52$, and 54 min, respectively, when incubated at $60{ }^{\circ} \mathrm{C}$. The enzymes were stable in solutions containing ethanol (10\%), and the kinetic parameters $\left(K_{m}\right.$ and $\left.V_{\max }\right)$ demonstrated that $\beta$-glucosidase from $L$. ramosa was competitively inhibited by glucose. The enzyme extract produced by $L$. ramosa was used for the saccharification of sugarcane bagasse pretreated with glycerol and the highest yield of glucose $(10.66 \%)$ was obtained at $24 \mathrm{~h}$ of hydrolysis. The characteristics of the enzymes, combined with the efficiency in hydrolyzing sugarcane bagasse, allow for the application of this enzyme extract to processes of cellulose saccharification for the production of second-generation ethanol.
\end{abstract}

\section{Introduction}

The growing concern about the scarcity of fossil fuels has prompted the search for alternative sources of fuel and renewable energy; particularly, the focus on the production of energy from vegetable biomass is increasing. Lignocellulosic biomass is an abundant renewable resource that is increasingly important for the production of biofuels, in particular bioethanol (Jing et al., 2015). In this context, the use of microbial enzymes capable of acting on the structure of plant polysaccharides for the production of fermentable sugars is an indispensable tool for obtaining biofuels (Pereira et al., 2015a).

Cellulolytic and hemicellulolytic enzymes are glycoside hydrolases involved in the degradation of plant biomass. The efficiency of the hydrolysis of cellulosic material is the result of synergistic actions of an enzyme system composed of at least three classes of enzymes, including: endoglucanases (EC 3.2.1.4), which are responsible for initiating hydrolysis by randomly cleaving internal bonds in cellulose with the release of different-sized oligosaccharides, thus making new ends accessible to exoglucanases; exoglucanases, exo- $\beta-1,4$-glucanase, or cellobiohydrolase (EC 3.2.1.91), which act on cellulose by removing units of cellobiose from the ends of the molecule; and $\beta-1,4$-glucosidases or cellobiases (EC 3.2.1.21), which hydrolyze cellobiose and other cellodextrins to glucose, controlling the overall rate of the reaction by preventing the accumulation of cellobiose and other cellodextrins in the reaction environment ( $\mathrm{Ng}$ et al., 2010; Liao et al., 2015).

Hemicellulases contribute to the disintegration of the polymeric structure of vegetable cell walls. Endo- $\beta-1,4$-xylanases (EC 3.2.1.8) cleave residues in the backbone of hemicellulose, drastically reducing the degree of polymerization, and $\beta$-xylosidases (EC 3.2.1.3.7) externally hydrolyze the xylan backbone and small xylooligosaccharides

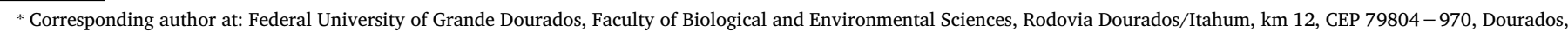
MS, Brazil.

E-mail address: rodrigoleite@ufgd.edu.br (R.S.R. Leite). 
into xylose (Gowdhaman et al., 2014; Knob et al., 2014).

In addition to the application described above, cellulases and hemicellulases are used in the production of juices, wines, beers, detergents, paper, and cellulose and can also be used as additives for animal feeds and in the stonewashing of fabrics by the textile industry (Garcia et al., 2015; Ng et al., 2010).

However, the high cost of producing these biocatalysts remains a problem for the conversion of lignocellulosic material via enzymatic hydrolysis and is a limitation to the production of ethanol from vegetable biomass (Bussamra et al., 2015). In this sense, recent studies have sought to reduce the final cost of these enzymes by prospecting strains with a potential to produce high concentrations of enzymes by low-cost methods (Costa et al., 2016; Delabona et al., 2013; Lan et al., 2013; Santos et al., 2016).

Previous studies conducted by our group have shown that the filamentous fungus Lichtheimia ramosa can be used for the production of cellulolytic and hemicellulolytic enzymes, when cultured in several byproducts of vegetable origin (Garcia et al., 2015; Gonçalves et al., 2016; Silva et al., 2013). The production of these biocatalysts by the microorganism, in low cost medium, and the scarcity of works using its enzymatic extract to saccharification of vegetable biomass, stimulated the development of the present work. In this study were evaluated several cultivation parameters for the production of cellulases and hemicellulases by $L$. ramosa by solid-state fermentation, and the enzymes were characterized biochemically and used in the saccharification of sugarcane bagasse to obtain fermentable sugars.

\section{Materials and methods}

\subsection{Microorganism}

The mesophilic filamentous fungus Lichtheimia ramosa was isolated from sugarcane bagasse obtained from the Usina de Açúcar e Álcool São Fernando, Dourados-MS, Brazil (Gonçalves et al., 2016). The fungus was cultured in Sabouraud dextrose agar at $28^{\circ} \mathrm{C}$ for $48 \mathrm{~h}$, the strain was stored at $4{ }^{\circ} \mathrm{C}$ in the Laboratory of Enzymology and Fermentation Processes (LEPFER).

\subsection{Inoculum}

The fungus was cultivated in inclined $250 \mathrm{~mL}$ Erlenmeyer flasks containing $40 \mathrm{~mL}$ of Sabouraud dextrose agar medium, at $28^{\circ} \mathrm{C}$ for $48 \mathrm{~h}$. The fungal suspension was obtained by gently scraping the surface of the culture medium, which contained $25 \mathrm{~mL}$ of nutrient solution composed of $0.1 \%$ ammonium sulfate, $0.1 \%$ magnesium sulfate heptahydrate, and $0.1 \%$ ammonium nitrate $(\mathrm{w} / \mathrm{v})$. The substrates (agroindustrial waste products) were inoculated with $5 \mathrm{~mL}$ of the suspension, amounting to $10^{6}$ spores/g of dry substrate.

\subsection{Solid-state fermentation}

Cellulases and hemicellulases were produced by fungus cultivation in $250 \mathrm{~mL}$ Erlenmeyer flasks containing $5 \mathrm{~g}$ of agroindustrial by-products (wheat bran, soy bran, corn cob, corn straw, rice husk, and sugarcane bagasse), and the initial moisture was adjusted to $75 \%$ with the nutrient solution (described in item 2.2). The enzymes were extracted from the fermented products $96 \mathrm{~h}$ after fermentation at $28^{\circ} \mathrm{C}$ (Costa et al., 2016; Santos et al., 2016). The ideal substrate for the production of the enzymes was used in the subsequent steps to evaluate the effects of moisture content $(50-80 \%)$, temperature $\left(20-45^{\circ} \mathrm{C}\right)$, and time of cultivation (24-144h). The conditions selected in each experiment were used in the subsequent cultivation. All the materials used were previously autoclaved for $20 \mathrm{~min}$ at $121^{\circ} \mathrm{C}$. The experiments were conducted in triplicate.

\subsection{Enzyme extraction}

The enzymes were extracted from the fermented products by adding $50 \mathrm{~mL}$ of distilled water and shaking at $100 \mathrm{rpm}$ for $1 \mathrm{~h}$. The sample was filtered through synthetic cloth (nylon) and centrifuged at $1500 \times g$ for $5 \mathrm{~min}$ at $10^{\circ} \mathrm{C}$. The supernatant was used as the enzyme extract in the subsequent experiments.

\subsection{Determination of cellulase and hemicellulase activities}

The activity of CMCase and xylanase was quantified using 3\% carboxymethylcellulose (C5678 Sigma) and 1\% (w/v) xylan (Birch-Wood Sigma), respectively, and the released reducing sugar was quantified by the 3,5-dinitrosalicylic acid (DNS) method (Miller, 1959). To determine the enzymatic activity of $\beta$-glucosidase and $\beta$-xylosidase, $250 \mu \mathrm{L}$ of $4 \mathrm{mM} p$-nitrophenyl- $\beta$-D-glucopyranoside (pNP $\beta \mathrm{G}$; Sigma) and $250 \mu \mathrm{L}$ of $4 \mathrm{mM} p$-nitrophenyl- $\beta$-D-xylopyranoside (pNP $\beta \mathrm{X}$; Sigma), respectively, were added to $50 \mu \mathrm{L}$ of enzyme extract with $250 \mu \mathrm{L}$ of $0.1 \mathrm{M}$ sodium

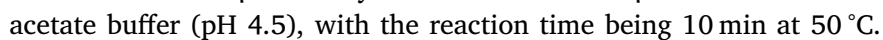
The enzymatic reaction was stopped by adding $2 \mathrm{~mL}$ of sodium carbonate $(2 \mathrm{M})$, and the released $p$-nitrophenol was quantified by spectrophotometry at $410 \mathrm{~nm}$ (Palma-Fernandez et al., 2002). One unit of enzyme activity was defined as the amount of enzyme required to release $1 \mu \mathrm{mol}$ of product per minute of reaction.

\subsection{Characterization of cellulases and hemicellulases produced by the fungus L. ramosa}

\subsubsection{Effect of $p H$ and temperature on enzymatic activity}

The optimum $\mathrm{pH}$ was determined by measuring the activity of the enzymes at $50^{\circ} \mathrm{C}$ within the $\mathrm{pH}$ range of 3.0-8.0, with increments of 0.5, using McIlvaine buffer solution (Mcllvaine, 1921). The optimum temperature was obtained by determining enzymatic activity within the range of $30-75^{\circ} \mathrm{C}$, with increments of $5^{\circ} \mathrm{C}$, at the optimum pH for each enzyme. $\mathrm{pH}$ stability was determined by incubating the enzymes for $24 \mathrm{~h}$ at $25^{\circ} \mathrm{C}$ at different values of $\mathrm{pH}$, using the following buffer solutions: 0.1 M McIlvaine ( $\mathrm{pH}$ 3.0-8.0), 0.1 M Tris- $\mathrm{HCl}$ ( $\mathrm{pH}$ 8.0-8.5), and $0.1 \mathrm{M}$ Glycine- $\mathrm{NaOH}$ ( $\mathrm{pH} 8.5-10.5$ ), with increments of 0.5 , taking the highest residual activity as the $100 \%$ value. Thermostability was determined by incubating the enzyme for $1 \mathrm{~h}$ at temperatures between $30^{\circ} \mathrm{C}$ and $70{ }^{\circ} \mathrm{C}$, with increments of $5{ }^{\circ} \mathrm{C}$, taking the highest residual activity after the samples were treated as the $100 \%$ value. The residual activities were determined under the optimum conditions of $\mathrm{pH}$ and temperature for each enzyme.

\subsubsection{Effect of ethanol on enzymatic activity}

Enzymatic activity was quantified by adding ethanol at different concentrations, ranging from $0 \%$ to $30 \%$, with $5 \%$ increments, to the reaction mixture. The activities were measured under optimal conditions of $\mathrm{pH}$ and temperature.

\subsubsection{Effect of glucose on the activity of $\beta$-glucosidase}

Enzymatic activity was quantified by adding glucose at different concentrations, ranging from $0 \mathrm{mM}$ to $200 \mathrm{mM}$, to the reaction mixture. The activities were measured under optimum conditions of $\mathrm{pH}$ and temperature.

\subsubsection{Determination of the kinetic parameters of $\beta$-glucosidase activity}

The Michaelis-Menten kinetic parameters were determined in the presence and absence of the inhibitor (glucose). In the experiments with the inhibitor, the concentration of glucose remained unchanged $(25 \mathrm{mM})$ in the reaction medium, and the concentration of the substrate ranged between $0.2 \mathrm{mM}$ and $25 \mathrm{mM}$. The values of $\mathrm{Km}$ and $V$ max were calculated from plots according to Lineweaver and Burk (1934). 


\subsection{Pretreatment of sugarcane bagasse using microwaves and glycerol}

Sugarcane bagasse was washed, dried at $40{ }^{\circ} \mathrm{C}$, and ground. The particles were retained in $3-\mathrm{mm}$ sieves. The pretreatment was performed by immersing $10 \mathrm{~g}$ of sugarcane bagasse in $30 \mathrm{~mL}$ of $100 \%$ glycerol for $24 \mathrm{~h}$. The material was subsequently transferred into a $250 \mathrm{~mL}$ round-bottom flask, which was then placed in a microwave oven and connected to a reflux condenser with rotation at the top of the oven. The samples were irradiated at $2450 \mathrm{MHz}$ for $5 \mathrm{~min}$. After irradiation, $30 \mathrm{~mL}$ of distilled water was added to the material, which was then shaken and filtered. The solid material was dried at $40^{\circ} \mathrm{C}$ and used in enzymatic saccharification assays. Sugarcane bagasse, both in natura and pretreated, was characterized with regard to cellulose, xylan, and lignin (Pereira et al., 2015b).

\subsection{Enzymatic saccharification of sugarcane bagasse}

The saccharification of in natura and pretreated bagasse was performed in $250 \mathrm{~mL}$ Erlenmeyer flasks, which were closed with latex stoppers, using 3\% (w/v) sugarcane bagasse, enzyme extract from the fungus $L$. ramosa (5 FPU of cellulase), and sodium acetate buffer $(0.1 \mathrm{M}$, $\mathrm{pH}$ 5.5), for a final volume of $25 \mathrm{~mL}$. The flasks were incubated in a shaker at $300 \mathrm{rpm}$ and $50^{\circ} \mathrm{C}$ for $48 \mathrm{~h}$. The content of the flasks was filtered, and the released glucose was quantified using a glucose-oxidase kit (Glicose-PP; Gold Analisa Diagnóstica Ltda, Brazil). The experiments were conducted in triplicate. Glucose yield was calculated using the following equation:

Yield $(\%)$

$$
\begin{aligned}
& =\frac{(\mathrm{g} \text { of glucose in the total volume of saccharification assay })}{(\mathrm{g} \text { of cellulose present in the sample of bagasse used in }} \times 100 \\
& \text { saccharification assay) }
\end{aligned}
$$

\subsection{Statistical analysis}

The experiments were performed in triplicate and the data were expressed as mean values of three independent assays. The statistical analysis of the data included ANOVA, followed by the Tukey's test with a level of significance of $1 \%$. The statistical software ASSISTAT (Silva and Azevedo, 2016) was used for the analyses.

\section{Results and discussion}

\subsection{Production of cellulases and hemicellulases by solid-state fermentation}

\subsubsection{Selection of substrates for enzyme production}

Among the evaluated substrates, wheat bran had the highest enzyme production: $43.2 \pm 1.3 \mathrm{U} / \mathrm{g}$ of dry substrate $(4.3 \mathrm{U} / \mathrm{mL})$ of CMCase, $\quad 162.2 \pm 4.2 \mathrm{U} / \mathrm{g} \quad(16.22 \mathrm{U} / \mathrm{mL})$ of $\beta$-glucosidase, $18.7 \pm 1.5 \mathrm{U} / \mathrm{g}(1.87 \mathrm{U} / \mathrm{mL})$ of xylanase, and $30.1 \pm 1 \mathrm{U} / \mathrm{g}(3.01 \mathrm{U} /$ $\mathrm{mL}$ ) of $\beta$-xylosidase (Table 1 ).

Several studies have emphasized the advantages of using wheat bran as a solid-state substrate for filamentous fungi cultivation for the production of cellulases and hemicellulases (Costa et al., 2016; Delabona et al., 2013; Gowdhaman et al., 2014; Kilikian et al., 2014; Santos et al., 2016).

As a substrate, wheat bran has good water-retaining capacity, and its physical structure favors the transfer of mass inside a solid matrix (Oliveira et al., 2016). In addition, its high protein (13-19\%), cellulose, and hemicellulose (above 39\%) content, combined with the low lignin content (3\%-6\%), are characteristics that favor microbial growth and, in turn, their production of enzymes (Falkoski et al., 2013; Kilikian et al., 2014). Therefore, wheat bran was used as substrate for the subsequent cultivations.
Table 1

Production of cellulases and hemicellulases by solid-state fermentation by the fungus $L$. ramosa in several agroindustrial residues containing an initial moisture of $75 \%$, incubated for $96 \mathrm{~h}$ at $28^{\circ} \mathrm{C}$.

\begin{tabular}{lcccc}
\hline Substrate & $\begin{array}{c}\text { CMCase (U/g } \\
\text { de substrate) }\end{array}$ & $\begin{array}{c}\text { B-glucosidase } \\
\text { (U/g de } \\
\text { substrate) }\end{array}$ & $\begin{array}{c}\text { Xylanase (U/g } \\
\text { de substrate) }\end{array}$ & $\begin{array}{c}\beta \text {-xylosidase } \\
\text { (U/g de } \\
\text { substrate) }\end{array}$ \\
\hline Wheat bran & $43.2 \pm 1.3^{\mathrm{a}}$ & $162.2 \pm 4.2^{\mathrm{a}}$ & $18.7 \pm 1.5^{\mathrm{a}}$ & $30.1 \pm 1.0^{\mathrm{a}}$ \\
Corn Straw & $15.2 \pm 0.2^{\mathrm{c}}$ & $3.5 \pm 0.4^{\mathrm{c}}$ & $5.4 \pm 0.9^{\mathrm{b}}$ & $1.4 \pm 0.2^{\mathrm{c}}$ \\
Corn cob & $2.0 \pm 0.6^{\mathrm{d}}$ & $2.7 \pm 0.2^{\mathrm{c}}$ & $2.1 \pm 0.4^{\mathrm{c}}$ & $0.8 \pm 0.1^{\mathrm{c}}$ \\
Rice peel & $2.2 \pm 0.1^{\mathrm{d}}$ & $0.6 \pm 0.0^{\mathrm{d}}$ & $5.1 \pm 1.3^{\mathrm{b}}$ & $0.3 \pm 0.1^{\mathrm{c}}$ \\
Soy bran & $2.2 \pm 0.3^{\mathrm{d}}$ & $11.5 \pm 0.7^{\mathrm{b}}$ & $5.6 \pm 1.4^{\mathrm{b}}$ & $1.2 \pm 0.1^{\mathrm{c}}$ \\
Sugarcane & $24.1 \pm 1.5^{\mathrm{b}}$ & $11.1 \pm 0.2^{\mathrm{b}}$ & $4.1 \pm 1.1^{\mathrm{b}}$ & $3.2 \pm 0.2^{\mathrm{b}}$ \\
$\quad$ & & & & \\
\hline \multicolumn{1}{c}{ bagasse } & & & & \\
\hline
\end{tabular}

Mean production with different letters indicate significant differences according to the Tukey's test $(\mathrm{p}<0.01$ ). The values $( \pm)$ represent the standard deviations of triplicate experiments.

\subsubsection{Effect of moisture, temperature, and time of cultivation on enzyme production}

The highest production of enzymes was obtained when the fungus $L$. ramosa was cultivated in wheat bran at an initial moisture of $60 \%$ for CMCase and $65 \%$ for $\beta$-glucosidase, xylanase, and $\beta$-xylosidase (Fig. 1).

Moisture content plays an important role in solid-state fermentation and directly influences microbial growth and, in turn, the production of the enzyme of interest. Low moisture content in a solid substrate decreases the solubility and diffusion of nutrients, as well as the stability of extracellular enzymes, and hinders microbial growth (Delabona et al., 2013; Sadaf and Khare, 2014). On the other hand, high levels of moisture may lead to the aggregation of substrate particles, thus reducing the porosity of the solid matrix, which limits heat dissipation and gas exchange (Oliveira et al., 2016).

The effect of the substrates initial moisture on the production of cellulases and hemicellulases under solid-state fermentation has been previously evaluated by Adhyaru et al. (2015). The authors evaluated the production of these enzymes by Aspergillus tubingensis under solidsate fermentation and obtained a significant increase in enzymatic activity after the optimization of this parameter.

The ideal temperature for the production of cellulases and hemicellulases by the fungus $L$. ramosa was $35^{\circ} \mathrm{C}$, presenting $132.6 \pm 4.1 \mathrm{U} / \mathrm{g}$ of dry substrate $(13.26 \mathrm{U} / \mathrm{mL})$ for CMCase, $249.0 \pm 8.5 \mathrm{U} / \mathrm{g}(24.9 \mathrm{U} / \mathrm{mL})$ for $\beta$-glucosidase, $28.0 \pm 1.1 \mathrm{U} / \mathrm{g}$ $(2.8 \mathrm{U} / \mathrm{mL})$ for xylanase, and $189.3 \pm 2.62 \mathrm{U} / \mathrm{g}(18.93 \mathrm{U} / \mathrm{mL})$ for $\beta$ xylosidase (Fig. 2).

The temperature of fermentation is extremely important for enzyme production, since changes in temperature directly affect cellular structures such as membranes and proteins (Juturu and Wu, 2014). The exposure of the microorganism to temperatures higher or lower than the optimal temperature considerably reduces its metabolic activity, with a consequent decrease in growth and synthesis of the enzymes of interest (Adhyaru et al., 2015).

The last fermentative parameter to be evaluated in the present study was the time of cultivation. For this assessment, the parameters selected in the previous assays, defined as optimal for the production of the enzymes, were maintained. The highest enzymatic activity was obtained at $96 \mathrm{~h}$ of fermentation for all of the evaluated enzymes: $168.1 \pm 2.2 \mathrm{U} / \mathrm{g}$ of dry substrate $(16.8 \mathrm{U} / \mathrm{mL})$ for CMCase; $270.4 \pm 8.9 \mathrm{U} / \mathrm{g}(27.0 \mathrm{U} / \mathrm{mL})$ for $\beta$-glucosidase; $34 \pm 0.8 \mathrm{U} / \mathrm{g}$ (3.4 U/ $\mathrm{mL})$ for xylanase, and $199.2 \pm 2.6 \mathrm{U} / \mathrm{g}(19.92 \mathrm{U} / \mathrm{mL})$ for $\beta$-xylosidase (Fig. 3). For each analyzed parameter (moisture, temperature, and time of cultivation), the optimal condition differs statistically $(\mathrm{p}<0.01)$ when compared to the other parameters.

The reduction in enzymatic activity observed after $96 \mathrm{~h}$ of fermentation can be explained by the change in the composition of the culture medium caused by microbial activity. Microbial growth in sequential cultivation results in the intake of nutrients and accumulation of 
A

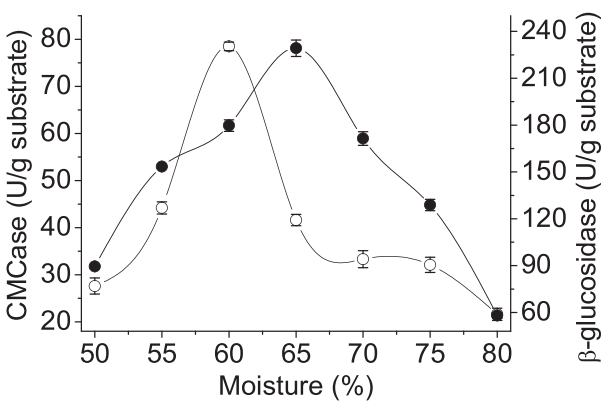

B

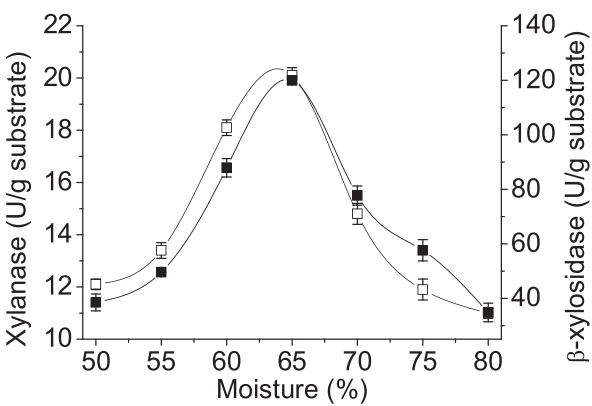

Fig. 1. Production of cellulases (A) and hemicellulases (B) by solid-state fermentation by the fungus $L$. ramosa in wheat bran with different moisture contents, incubated for $96 \mathrm{~h}$ at $28^{\circ} \mathrm{C}$. Error bars represent the mean standard deviation of triplicate experiments. (O) CMCase; (๑) $\beta$-glucosidase; $(\square)$ Xylanase; $\beta$-xylosidase. metabolites that are not removed from the environment because of the characteristics of this type of process. Some of the main changes are the accumulation of metabolic heat, changes in $\mathrm{pH}$, and the secretion of proteolytic enzymes and enzyme inhibitors. These may result in the denaturation or inhibition of the enzymes that were previously secreted into the culture medium (Sadaf and Khare, 2014; Xin and Geng, 2010).

The high production of the evaluated enzymes and the short duration of cultivation are extremely desirable characteristics for the industrial application of these biocatalysts. The highest production of cellulases and hemicellulases by the fungus $L$. ramosa was obtained with a time of cultivation $(96 \mathrm{~h})$ that is shorter than the time reported in previous studies. Soni and Soni (2010) reported a maximal production of endoglucanase $(0.44 \mathrm{U} / \mathrm{mL})$ by the fungus Chaetomium erraticum when cultivating under solid-state fermentation for $192 \mathrm{~h}$ using wheat bran as substrate. Pereira et al. (2015a) reported a maximal production of $\beta$-glucosidase $(41.8 \mathrm{U} / \mathrm{g}$ ) by the fungus Thermomucor indicae-seudaticae N31 under solid-state fermentation for $192 \mathrm{~h}$ using wheat bran. Terrasan et al. (2010) optimized the production of hemicellulases by the fungus Penicillium janczewskii under submerged cultivation, obtaining $15.19 \mathrm{U} / \mathrm{mL}$ of xylanase and $0.16 \mathrm{U} / \mathrm{mL}$ of $\beta$-xylosidase at $168 \mathrm{~h}$ of cultivation. Zimbardi et al. (2013) reported the production of cellulases and hemicellulases by the fungus Colletotrichum graminicola in wheat bran, having achieved maximal production of $\beta$-glucosidase $(159.3 \mathrm{U} / \mathrm{g})$ and $\beta$-xylosidase $(128 \mathrm{U} / \mathrm{g})$ at $168 \mathrm{~h}$ of cultivation and the maximum production of xylanase $(378.1 \mathrm{U} / \mathrm{g})$ at $192 \mathrm{~h}$.

The optimization of the parameters of $L$. ramosa cultivation resulted in production of the enzymes of interest with a markedly higher production than in the initial experiments, when the conditions were still not optimized (Table 1; Fig. 3).

Considering the aspects of production cost reduction and application of these biocatalysts in vegetable polysaccharide saccharification, the simultaneous production of different enzymes involved in the hydrolysis of vegetable biomass is an additional advantage of this fungal strain.
3.2. Characterization of the cellulases and hemicellulases produced by the fungus $L$. ramosa

\subsubsection{Effect of $\mathrm{pH}$ and temperature on enzymatic activity}

The highest catalytic activities of the xylanase, $\beta$-xylosidase, CMCase, and $\beta$-glucosidase produced by $L$. ramosa were obtained at $\mathrm{pH}$ $4.5,4.5,5.0$, and 5.5, respectively. With regard to the optimal temperature, the highest activity of CMCase and $\beta$-glucosidase was obtained at $60^{\circ} \mathrm{C}$ and $65^{\circ} \mathrm{C}$, respectively, and of xylanase and $\beta$-xylosidase at $55^{\circ} \mathrm{C}$ (Table 2).

The cellulases and hemicellulases exhibited good structural stability. CMCase, $\beta$-glucosidase, and $\beta$-xylosidase retained their original activity after $24 \mathrm{~h}$ at $\mathrm{pH}$ ranging from 3.5 to 10.5 . The xylanase was less pH-stable (4.5-9.5) than the other evaluated enzymes. With regard to thermal stability, approximately $95 \%$ of the initial catalytic activity was recovered after $1 \mathrm{~h}$ at $55^{\circ} \mathrm{C}$ for all the assessed enzymes (Table 2).

The enzymes produced by $L$. ramosa exhibited optimal activity at acidic $\mathrm{pH}$ values (4.5-5.5) and at high temperatures $\left(55-65^{\circ} \mathrm{C}\right)$. In addition, these biomolecules exhibited structural stability over wide ranges of $\mathrm{pH}$ and temperature, a desirable characteristic in industrial application.

Considering that the pretreatment of lignocellulosic biomass is usually performed in acidic solutions (Ng et al., 2010; Falkoski et al., 2013), the findings described above support the use of the enzyme complex produced by $L$. ramosa in processes of vegetable biomass saccharification. Moreover, sustaining catalytic activity at high temperatures is desirable for the application of biocatalysts in various industrial processes; however, this characteristic is not usually found in enzymes produced by mesophilic fungi (Garcia et al., 2015).

Previous studies have reported an optimal pH of 5.0 for endoglucanases of other fungal species (Olajuyigbe and Ogunyewo, 2016). The optimal pH for xylanase produced by Trichoderma inhamatum was 5.5 (Silva et al., 2015) and 4.7 for $\beta$-xylosidase produced by Colletotrichum graminicola (Zimbardi et al., 2013).

The enzymes assessed in the present study exhibited optimal activity at temperatures higher than $50{ }^{\circ} \mathrm{C}$. In general, enzymes produced by mesophilic microorganisms act at more moderate temperatures (Garcia et al., 2015; Gomes et al., 2007). Liao et al. (2015) studied the
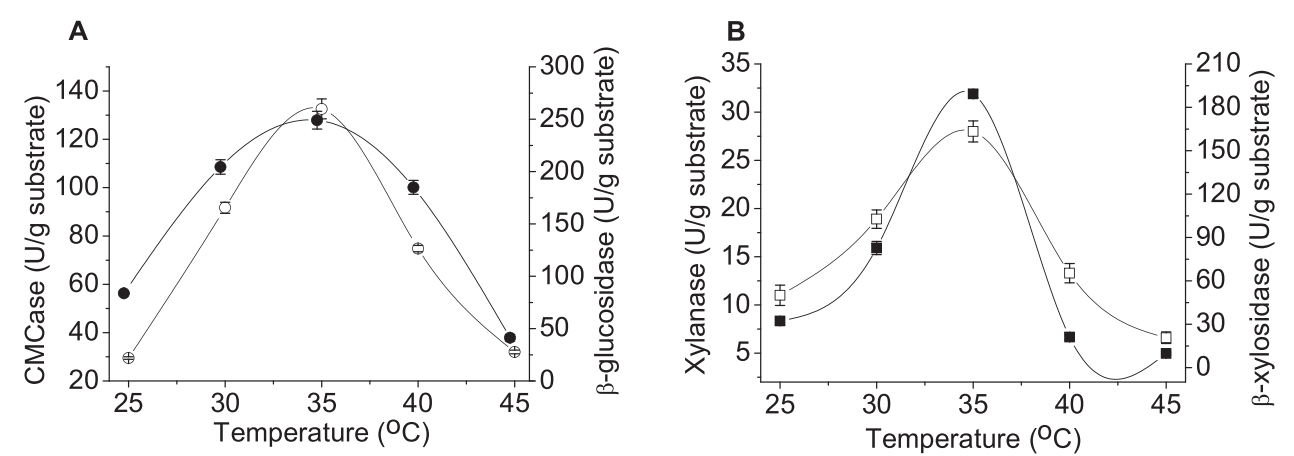

Fig. 2. Production of cellulases (A) and hemicellulases (B) by solid-state fermentation by the fungus $L$. ramosa at different temperatures, using wheat bran with $60 \%$ moisture for CMCase and $65 \%$ moisture for the remaining enzymes, incubated for $96 \mathrm{~h}$. Error bars represent the mean standard deviation of triplicate experiments. (O) CMCase; $(\bullet) \beta$-glucosidase; $(\square)$ Xylanase; ( $\square$ ) $\beta$-xylosidase. 

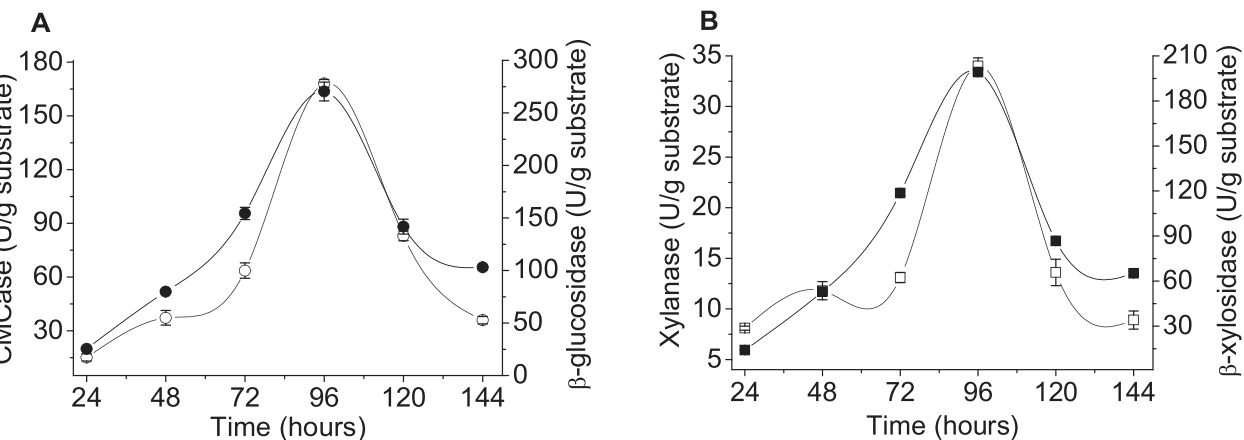

Fig. 3. Production of cellulases (A) and hemicellulases (B) by the fungus $L$. ramosa during of cultivation, using wheat bran with $60 \%$ moisture for CMCase and $65 \%$ moisture for the remaining enzymes, incubated at $35^{\circ} \mathrm{C}$. Error bars represent the mean standard deviation of triplicate experiments. (O) CMCase; (O) $\beta$ glucosidase; $(\square)$ Xylanase; ( $\square$ ) $\beta$-xylosidase.
Table 2

Effect of $\mathrm{pH}$ and temperature on the activities of the cellulases and hemicellulases produced by the fungus $L$. ramosa.

\begin{tabular}{lcccc}
\hline Enzymes & Optimum pH & $\begin{array}{c}\text { Optimum } \\
\text { Temperature }\left({ }^{\circ} \mathrm{C}\right)\end{array}$ & $\begin{array}{c}\text { Stability } \\
\mathrm{pH}\end{array}$ & $\begin{array}{c}\text { Stability } \\
\text { Temperature }\left({ }^{\circ} \mathrm{C}\right)\end{array}$ \\
\hline CMCase & 5.0 & 60 & $3.5-10.5$ & $30-55$ \\
$\beta$-glucosidase & 5.5 & 65 & $3.5-10.5$ & $30-55$ \\
Xylanase & 4.5 & 55 & $4.5-9.5$ & $30-55$ \\
$\beta$-xylosidase & 4.5 & 55 & $3.5-10.5$ & $30-55$ \\
\hline
\end{tabular}

fungus Penicillium oxalicum GZ-2 and reported an optimal temperature of $50{ }^{\circ} \mathrm{C}$ for CMCase. Silva et al. (2016) reported optimal activity of the $\beta$-glucosidase produced by the fungus Myceliophthora heterothallica at $60{ }^{\circ} \mathrm{C}$. Ahmed et al. (2016) studied the xylanase produced by Aspergillus terreus KP90097 and reported an optimal temperature of $50{ }^{\circ} \mathrm{C}$. The $\beta$ xylosidase produced by Phanerochaete chrysosporium exhibited optimal activity at $50^{\circ} \mathrm{C}$ (Huy et al., 2015).

The cellulases and hemicellulases produced by $L$. ramosa were thermoinactivated when incubated at $60^{\circ} \mathrm{C}$. The half-lives $\left(t_{1 / 2}\right)$ of CMCase, $\beta$-glucosidase, xylanase, and $\beta$-xylosidase were $68,59,52$, and 54 min, respectively (Fig. 4).

The enzymes CMCase and $\beta$-glucosidase were more thermostable than the cellulases produced by other mesophilic fungal species and even more thermostable than some produced by thermophilic species (Santos et al., 2016; Souza et al., 2010; Zanoelo et al., 2004). The xylanase and $\beta$-xylosidase also exhibited high thermal stability, especially when compared with other biocatalysts with the same biological function produced by different species (Jiang et al., 2010; Katapodis et al., 2006; Silva et al., 2015; Yan et al., 2008).

The thermal stability of the enzymes produced by L. ramosa is another interesting characteristic for their use in biotechnological processes. High thermostability is an important property for the industrial application of cellulases and hemicellulases because the rate of the conversion of the substrate into the product increases with temperature (Leghlimi et al., 2013). Saccharification of vegetable biomass at high temperatures contributes to a reduced risk of microbial contamination

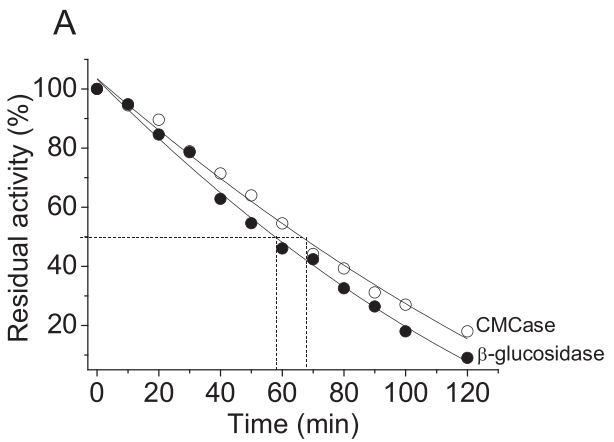

of the process and prevents early intake of the primary product of hydrolysis, i.e. glucose, by undesirable microorganisms (Leghlimi et al., 2013; Olajuyigbe and Ogunyewo, 2016).

\subsubsection{Effect of ethanol on enzymatic activity}

The enzymes evaluated in the present study maintained their catalytic activities in solutions containing up to $10 \%$ of ethanol. The lowest recovery obtained at this concentration of ethanol was $70 \%$ of the original activity. $\beta$-glucosidase was activated in a solution containing $5 \%$ of ethanol, with an approximate $20 \%$ increase in its activity relative to its initial activity (Fig. 5). The increase in catalytic potential that is observed for $\beta$-glucosidase is usually related to the glucosyltransferase activity (Villena et al., 2006); in this case, ethanol may act as the preferred acceptor of the intermediary glycosyl cation during substrate hydrolysis, increasing the rate of the reaction (Krisch et al., 2012).

Assessing the effect of ethanol on enzymatic activity is essential in the study of cellulases and hemicellulases because these enzymes are exposed to significant concentrations of ethanol in many industrial applications (Garcia et al., 2015; Sun and Cheng, 2002).

The concentration of ethanol obtained in the final stages of traditional fermentative processes is approximately $10 \%(\mathrm{v} / \mathrm{v})(\mathrm{Gu}$ et al., 2001). In this context, it is possible to infer that the enzymatic cocktail produced by $L$. ramosa is sufficiently stable to be used in processes that involve alcoholic fermentation.

\subsubsection{Effect of glucose on the activity of $\beta$-glucosidase}

The $\beta$-glucosidase produced by $L$. ramosa was inhibited by glucose, and $50 \%$ of its initial catalytic activity was maintained in solutions containing $50 \mathrm{mM}$ glucose. When the concentration of glucose was increased to $150 \mathrm{mM}$, the recovered enzymatic activity was only $20 \%$ of the initial activity (Fig. 6A).

Most microbial $\beta$-glucosidases are strongly inhibited by glucose. Santos et al. (2016) reported the inhibition of $\beta$-glucosidase of Gongronella butleri by glucose, with only $50 \%$ of catalytic activity being obtained in solutions containing $10 \mathrm{mM}$ glucose. The $\beta$-glucosidase produced by Periconia sp. was strongly inhibited in solutions containing $10 \mathrm{mM}$ glucose (Harnpicharnchai et al., 2009).

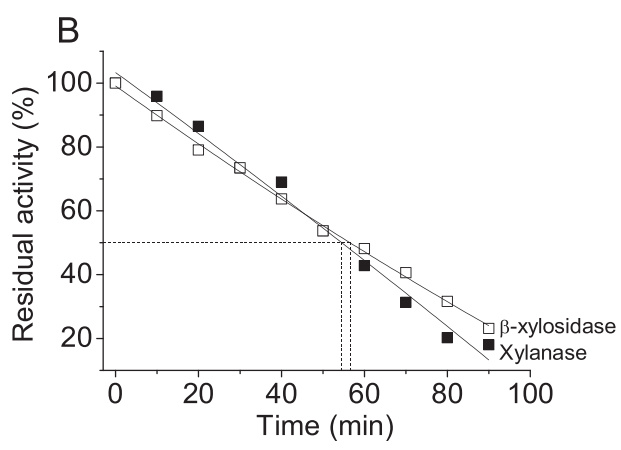

Fig. 4. Residual activity of the cellulases (A) and hemicellulases (B) produced by the fungus L. ramosa during incubation at $60^{\circ} \mathrm{C}$. 

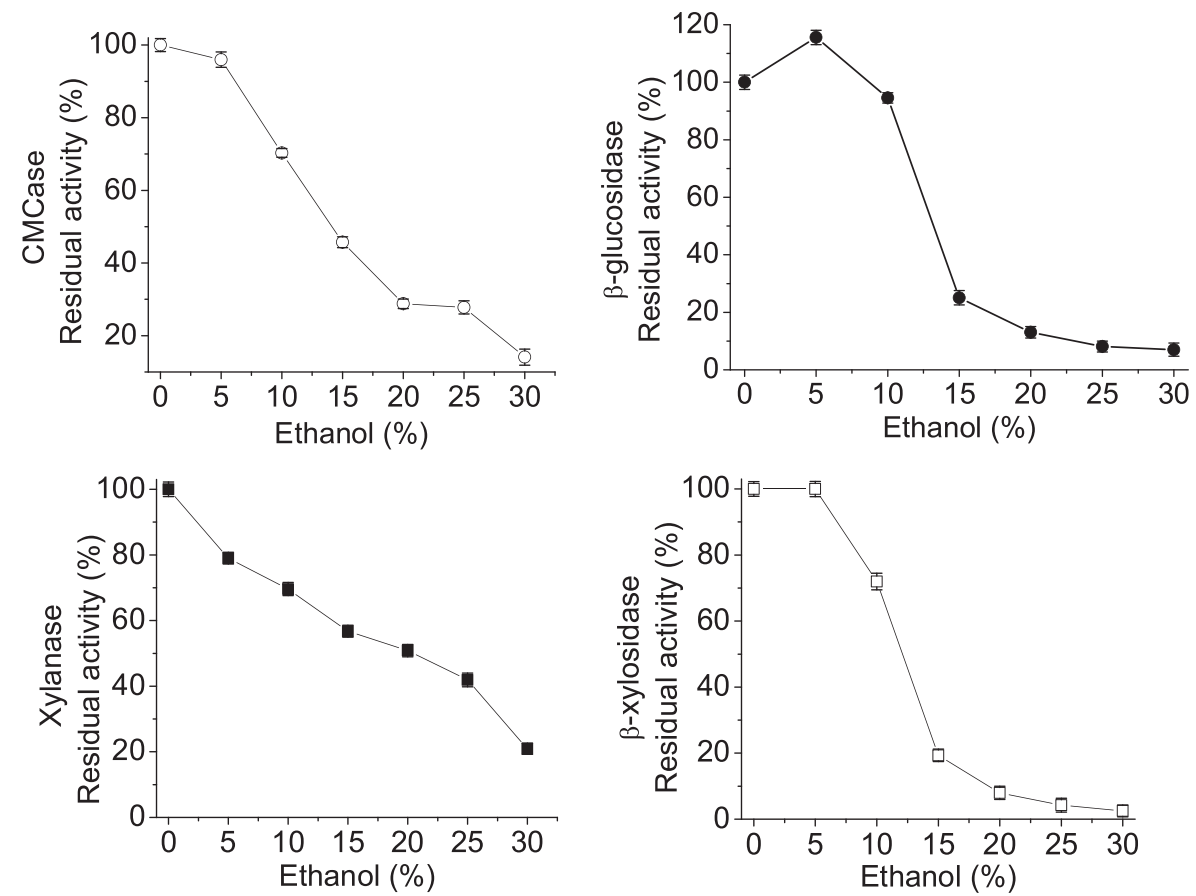

Fig. 5. Effect of ethanol on the activity of cellulases and hemicellulases produced by the fungus L. ramosa. Error bars represent the mean standard deviation of triplicate experiments.

An alternative to overcoming inhibition by fermentable sugars is to associate enzymatic hydrolysis of cellulose with alcoholic fermentation by a process called saccharification and simultaneous fermentation, in which glucose released by the enzymes is converted into ethanol by fermenting microorganisms (Pereira et al., 2015a; Scott et al., 2013).

The kinetic parameters $\left(V_{\max }\right.$ and $\left.K_{m}\right)$ of $\beta$-glucosidase produced by $L$. ramosa were calculated in the presence and absence of glucose in the reaction mixture by Lineweaver-Burk double reciprocal plot analysis (Fig. 6B).

In the assays performed without the addition of glucose, the $V_{\max }$ and $K_{m}$ values were $35.0 \mu \mathrm{mol} / \mathrm{min}$ and $0.40 \mathrm{mM}$, respectively. $V_{\max }$ and $K_{m}$ obtained with the addition of glucose to the reaction mixture were $35.0 \mu \mathrm{mol} / \mathrm{min}$ and $1.77 \mathrm{mM}$, respectively.

The linearity observed in the Lineweaver-Burk double reciprocal plot confirms the Michaelis-Menten kinetic profile of the enzyme, with $\mathrm{r}^{2}=0.998$. The results of the kinetic parameters indicate that the inhibition of the enzyme by glucose was competitive, in which $K_{m}$ increased with the presence of the inhibitor; however, $V_{\max }$ remained unchanged (Fig. 6B).

In this type of inhibition, the inhibitor and the substrate compete for the enzyme active site. The increase in substrate concentration favors

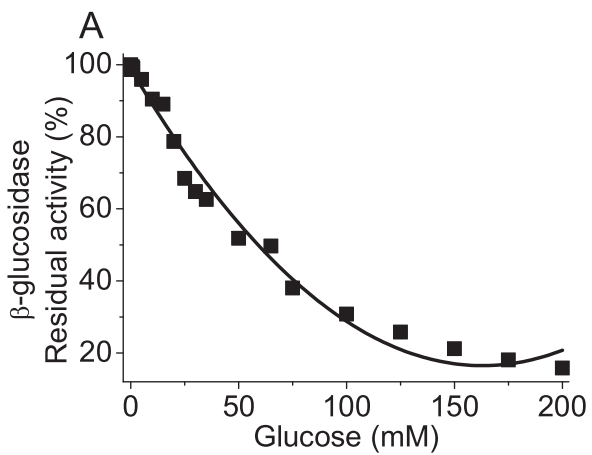

its binding to the active site, thus reversing the inhibiting effect of glucose, which results in the increase in $K_{m}$, while $V_{\max }$ remains unchanged (Krisch et al., 2012; Leite et al., 2008).

\subsection{Enzymatic saccharification of sugarcane bagasse}

The enzyme extract produced by $L$. ramosa was used in the saccharification of sugarcane bagasse in natura and pretreated with glycerol. After $24 \mathrm{~h}$ of hydrolysis, $2.05 \%$ of the cellulose in the in natura bagasse and $10.6 \%$ of the cellulose in the pretreated bagasse were converted to glucose (Fig. 7A).

The low conversion of cellulose into glucose obtained in the enzyme hydrolysis of in natura sugarcane bagasse is probably associated with the high degree of organization of lignin and hemicellulose, which hinders the action of cellulolytic enzymes and reduces the efficiency of the process (Chandel et al., 2012; Falkoski et al., 2013).

Pretreated sugarcane bagasse was used to assess the efficiency of the hydrolysis process over time because the highest rate of conversion was obtained with this product. The highest yield was obtained at $24 \mathrm{~h}$ of hydrolysis $(1.45 \mathrm{mg} / \mathrm{mL})$ and a marked decrease was observed at $48 \mathrm{~h}$ (Fig. 7B).

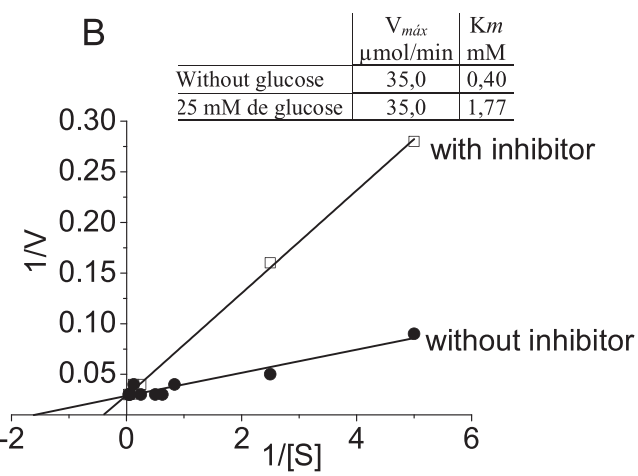

Fig. 6. Effect of glucose concentration on the activity of $\beta$-glucosidase (A). Lineweaver-Burk plotting to determine the kinetic parameters $\left(K_{m}\right.$ and $\left.V_{\text {max }}\right)$ for $\beta$ glucosidase (B). 

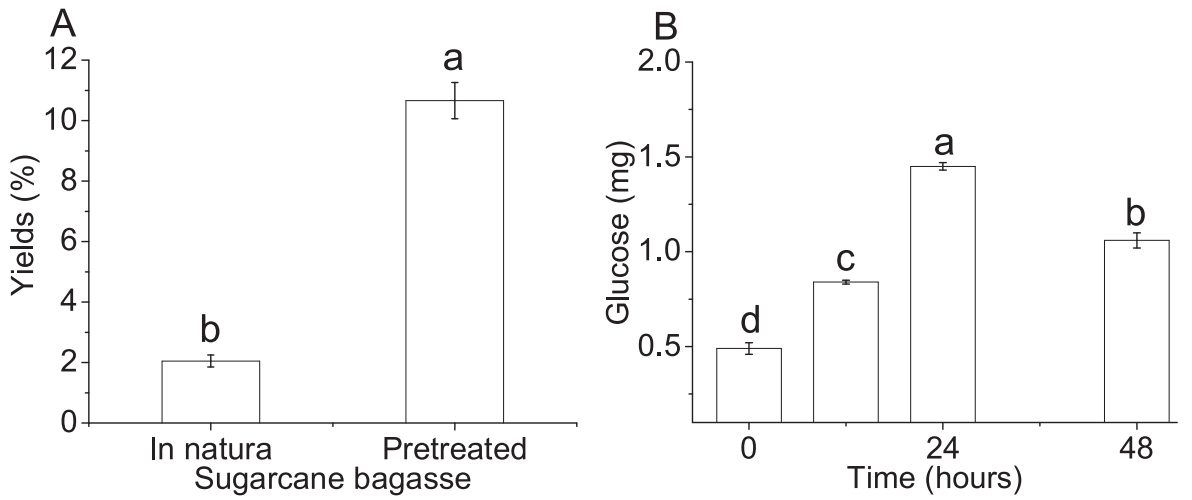

Fig. 7. Hydrolysis of sugarcane bagasse using enzyme extract produced by L. ramosa. Glucose yields obtained after $24 \mathrm{~h}$ of saccharification of in natura and pretreated sugarcane bagasse (A). Glucose yield versus duration of enzymatic saccharification of pretreated sugarcane bagasse (B). Different letters indicate significant differences according to the Tukey's test $(\mathrm{p}<0.01)$. The values $( \pm)$ represent the standard deviations of triplicate experiments.
The decrease in the amount of glucose at $48 \mathrm{~h}$ of hydrolysis may be explained by the glycosyltransferase activity of $\beta$-glucosidase. According to Bhatia et al. (2002), the increase in the concentration of glucose in the reaction environment favors the synthesis of cellobiose by $\beta$-glucosidase (transglycosylation activity). Additional evidence that reinforces this hypothesis is the increase in the catalytic activity of this enzyme in solutions containing ethanol, which was shown in previous assays (Fig. 5), in which the enzyme uses ethanol as an acceptor of glucose, with the release of ethyl glucosides. This property of $\beta$-glucosidases has been demonstrated in previous studies (Krisch et al., 2012; Leite et al., 2008).

The glucose yields obtained in the present study from pretreated sugarcane bagasse are even more significant when they are compared with the results from the literature. Moretti et al. (2012) used enzymes from Myceliophthora thermophila in the saccharification of pretreated sugarcane bagasse with glycerol, and the conversion of cellulose into glucose was 4\%. Zimbardi et al. (2013) studied the enzyme complex produced by the fungus Colletotrichum graminicola and obtained a maximum yield of glucose of $4.4 \%$ after $72 \mathrm{~h}$ of enzymatic hydrolysis.

The results of this study confirm the potential of the enzyme extract produced by L. ramosa for the conversion of lignocellulosic biomass and encourage continuing studies on the optimization of the process of enzymatic saccharification of sugarcane bagasse.

\section{Conclusion}

The results described in the present study indicate that the fungus Lichtheimia ramosa is able to produce cellulases and hemicellulases by solid-state fermentation, using low-cost methods. The high production of $\beta$-glucosidase and $\beta$-xylosidase by this microorganism contributes to the formulation of enzyme cocktails to supplement the low activity of these enzymes observed in enzyme extracts produced by other fungal species.

The characteristics of the cellulases and hemicellulases produced by $L$. ramosa favor the application of these biocatalysts in industrial processes, especially in the saccharification of vegetable biomass for the production of ethanol. Another important characteristic of this fungal species that was observed herein is the simultaneous and significant production of different enzymes involved in the hydrolysis of vegetable biomass, which contributes to reducing the costs of this process.

\section{Conflict of interest}

The authors declare no conficts of interest.

\section{Acknowledgements}

The authors gratefully acknowledge the Professor Dr. Mauricio Boscolo (process FAPESP 2011/06923-8) for the treatment of sugarcane bagasse, the financial support of the Conselho Nacional de
Desenvolvimento Científico e Tecnológico - CNPq (444630/2014-7), Fundação de Apoio ao Desenvolvimento do Ensino, Ciência e Tecnologia do Estado de Mato Grosso do Sul - FUNDECT (23/200.211/ 2014), and Coordenação de Aperfeiçoamento Pessoal de Nível Superior - CAPES.

\section{References}

Adhyaru, D.N., Bhatt, N.S., Modi, H.A., 2015. Optimization of upstream and downstream process parameters for cellulase-poor-thermosolvent-stable xylanase production by Apergillus tubingensis FDHN1. Bioresour. Bioprocess 2, 1-14.

Ahmed, S.A., Saleh, S.A.A., Mostafa, F.A., El Aty, A.A.A., AMMAR, H.A.M., 2016. Characterization and valuable applications of xylanase from endophytic fungus Aspergillus terreus KP900973 isolated from Corchorus olitorius. Biocatal. Agric. Biotechnol. 7, 134-144.

Bhatia, Y., Mishra, S., Bisaria, V.S., 2002. Microbial $\beta$-Glucosidases: cloning, properties, and applications. Crit. Rev. Biotechnol. 22, 375-407.

Bussamra, B.C., Freitas, S., Costa, A.C., 2015. Improvement on sugar cane bagasse hydrolysis using enzymatic mixture designed cocktail. Bioresour. Technol. 187, $173-181$.

Chandel, A.K., Silva, S.S., Carvalho, W., Singh, O.V., 2012. Sugarcane bagasse and leaves: foreseeable biomass of biofuel and bio-products. J. Chem. Technol. Biotechnol. 87, $11-20$.

Costa, A.C., Scalabrini, R.P., Silvestre, M.A., Rodrigues, A., Paz, M.F., Fonseca, G.G., Leite, R.S.R., 2016. Production of xylanase by a new strain of Thermoascus aurantiacus: obtainment of enzymatic extract with reduced cellulolytic activity for application in pulp and paper industries. Biosci. J. 32, 1040-1048.

Delabona, P.S., Pirota, R.D.P.B., Codima, C.A., Tremacoldic, C.R., Rodrigues, A., Farinas, C.S., 2013. Effect of initial moisture content on two Amazon rainforest Aspergillus strains cultivated on agro-industrial residues: biomass-degrading enzymes production and characterization. Ind. Crops. Prod. 42, 236-242.

Falkoski, D.L., Guimaraes, V.M., Almeida, M.N., Alfenas, A.C., Colodette, J.L., Rezende, S.T., 2013. Chrysoporthe cubensis: a new source of cellulases and hemicellulases to application in biomass saccharification processes. Bioresour. Technol. 130, 296-305.

Garcia, N.F.L., Santos, F.R.S., Gonçalves, F.A., Paz, M.F., Fonseca, G.G., Leite, R.S.R., 2015. Production of $\beta$-glucosidase on solid state fermentation by Lichtheimia ramosa in agroindustrial residues: characterization and catalytic properties of the enzymatic extract. Electron. J. Biotechnol. 18, 314-319.

Gomes, E., Guez, M.A.U., Martin, N., Da-Silva, R., 2007. Enzimas termoestáveis: fontes, produção e aplicação industrial. Quim. Nova. 30, 136-145.

Gonçalves, F.A., Leite, R.S.R., Rodrigues, A., Argandoña, E.J.S., Fonseca, G.G., 2016 Isolation, identification and characterization of a novel high level $\beta$-glucosidase producing Lichtheimia ramosa strain. Biocatal. Agric. Biotechnol. 2, 377-384.

Gowdhaman, D., Manaswini, V.S., Jayanthi, V., Dhanasri, M., Jeyalakshmi, G., Gunasekar, V., Sugumaran, K.R., Ponnusami, V., 2014. Xylanase production from Bacillus aerophilus KGJ2 and its application in xylooligosaccharides preparation. Int. J. Biol. Macromol. 64, 90-98.

Gu, Y., Qiao, M., Zhou, Q., Zhou, Z., Chen, G., 2001. Hyperproduction of alcohol using yeast fermentation in highly concentrated molasses medium. Tsinghua Sci. Technol. 3, 225-230.

Harnpicharnchai, P., Champreda, V., Sornlake, W., Eurwilaichitr, L., 2009. A thermotolerant $\beta$-glucosidase isolated from an endophytic fungi, Periconia sp., with a possible use for biomass conversion to sugars. Protein Expression Purif. 67, 61-69.

Huy, N.D., Nguyen, C.L., Seo, J.W., Kim, D.H., Park, S.M., 2015. Putative endoglucanase PcGH5 from Phanerochaete chrysosporium is a $\beta$-xylosidase that cleaves xylans in synergistic action with endo-xylanase. J. Biosci. Bioeng. 119, 416-420.

Jiang, Z., Cong, Q., Yan, Q., Kumar, N., Du, X., 2010. Characterization of a thermostable xylanase from Chaetomium sp. and its application in Chinese steamed bread. Food Chem. 120, 457-462.

Jing, L., Zhao, S., Xue, J.L., Zhang, Z., Yang, Q., Xian, L., Feng, J.X., 2015. Isolation and characterization of a novel Penicillium oxalicum strain Z1-3 with enhanced cellobiohydrolase production using cellulase-hydrolyzed sugarcane bagasse as carbon source. Ind. Crops. Prod. 77, 666-675. 
Juturu, V., Wu, J.C., 2014. Microbial cellulases: engineering, production and applications. Renew. Sustain. Energy Rev. 33, 188-203.

Katapodis, P., Nerinckx, W., Claeyssens, M., Christakopoulos, P., 2006. Purification and characterization of a thermostable intracellular $\beta$-xylosidase from the thermophilic fungus Sporotrichum thermophile. Process. Biochem. 41, 2402-2409.

Kilikian, B.V., Afonso, L.C., Souza, T.F.C., Ferreira, R.G., Pinheiro, I.R., 2014. Filamentous fungi and media for cellulase production in solid state cultures. Braz. J. Microbiol. 45, 279-286.

Knob, A., Fortkamp, D., Prolo, T., Izidoro, S.C., Almeida, J.M., 2014. Agro-residues as alternative for xylanase production by filamentous fungi. BioResources 9 , 5738-5773.

Krisch, J., Bencsik, O., Papp, T., Vágvölgyi, C., Takó, M., 2012. Characterization of a $\beta$ glucosidase with transgalactosylation capacity from the zygomycete Rhizomucor miehei. Bioresour. Technol. 114, 555-560.

Lan, T.Q., Wei, D., Yang, S.T., Liu, X.G., 2013. Enhanced cellulase production by Trichoderma viride in a rotating fibrous bed bioreactor. Bioresour. Technol. 133, 175-182.

Leghlimi, H., Meraihi, Z., Boukhalfa-Lezzar, H., Copinet, E., Duchiron, F., 2013. Production and characterization of cellulolytic activities produced by Trichoderma longibrachiatum (GHL). Afr. J. Biotechnol. 12, 465-475.

Leite, R.S.R., Alves-Prado, H.F., Cabral, H., Pagnocca, F.C., Gomes, E., Silva, R., 2008. Production and characteristics comparison of crude $\beta$-glucosidases produced by microorganisms Thermoascus aurantiacus e Aureobasidium pullulans in agricultural wastes. Enzyme Microb. Technol. 43, 391-395.

Liao, H., Fan, X.T., Mei, X., Wei, Z., Raza, W., Shen, Q., Xu, Y., 2015. Production and characterization of cellulolytic enzyme from Penicillium oxalicum GZ-2 and its application in lignocellulose saccharification. Biomass Bioenergy 74, 122-134.

Lineweaver, H., Burk, D., 1934. The Determination of enzyme dissociation constants. J. Am. Chem. Soc. 56, 658-666.

Mcllvaine, T.C., 1921. A buffer solution for colorimetric comparison. J. Biol. Chem. 49, 183-1861921.

Miller, G.L., 1959. Use of Dinitrosalicylic acid reagent for determination of reducing sugar. Anal. Chem. 31, 426-428.

Moretti, M.M.S., Bocchini-Martins, D.A., Da-Silva, R., Rodrigues, A., Sette, L.D., Gomes, E., 2012. Selection of thermophilic and thermotolerant fungi for the production of cellulases and xylanases under solid-state fermentation. Braz. J. Microbiol. 43, 1062-1071.

Ng, I.S., Li, C.W., Chan, S.P., Chir, J.L., Chen, P.T., Tong, C.G., Yu, S.M., 2010. High-level production of a thermoacidophilic $\beta$-glucosidase from Penicillium citrinum YS40-5 by solid-state fermentation with rice bran. Bioresour. Technol. 101, 1310-1317.

Olajuyigbe, F.M., Ogunyewo, O.A., 2016. Enhanced production and physicochemical properties of thermostable crude cellulase from Sporothrix carnis grown on corncob. Biocatal. Agric. Biotechnol. 7, 110-117.

Oliveira, A.P.A., Silvestre, M.A., Garcia, N.F.L., Aalves-Prado, H.F., Rodrigues, A., Paz, M.F., Fonseca, G.G., Leite, R.S.R., 2016. Production and catalytic properties of amylases from Lichtheimia ramosa and Thermoascus aurantiacus by solid-state fermentation. Sci. World J. 2016, 1-10.

Palma-Fernandez, E.R.D., Gomes, E., Da-Silva, R., 2002. Purification and characterization of two $\beta$-Glucosidases from thermophilic fungus Thermoascus aurantiacus. Folia Microbiol. 47, 685-690.

Pereira, J.C., Leite, R.S.R., Alves-Prado, H.F., Bocchini-Martins, D.A., Gomes, E., Da-Silva, R., 2015a. Production and characterization of $\beta$-glucosidase obtained by the solidstate cultivation of the thermophilic fungus Thermomucor indicae-seudaticae N31.
Appl. Biochem. Biotechnol. 175, 723-732.

Pereira, J.C., Marques, N.P., Rodrigues, A., Oliveira, T.B., Boscolo, M., Da Silva, R. Gomes, E., Bocchini-Martins, D.A., 2015b. Thermophilic fungi as new sources for production of cellulases and xylanases with potential use in sugarcane bagasse saccharification. J. Appl. Microbiol. 118, 928-939.

Sadaf, A., Khare, S.K., 2014. Production of Sporotrichum thermophile xylanase by solid state fermentation utilizing deoiled Jatropa curcas seed cake and its application in xylooligosachharide synthesis. Bioresour. Technol. 153, 126-130.

Santos, F.R.S., Garcia, N.F.L., Paz, M.F., Fonseca, G.G., Leite, R.S.R., 2016. Production and characterization of $\beta$-glucosidase from Gongronella butleri by solid-state fermentation. Afr. J. Biotechnol. 15, 633-641.

Scott, F., Quintero, J., Morales, M., Conejeros, R., Cardona, C., Aroca, G., 2013. Process design and sustainability in the production of bioethanol from lignocellulosic materials. Electron. J. Biotechnol. 16, 1-16.

Silva, F.A.S., Azevedo, C.A.V., 2016. The assistat software version 7.7 and its use in the analysis of experimental data. Afr. J. Agric. Res. 11, 3733-3740.

Silva, C.A.A., Lacerda, M.P.F., Leite, R.S.R., Fonseca, G.G., 2013. Production of enzymes from Lichtheimia ramosa using Brazilian savannah fruit wastes as substrate on solid state bioprocesses. Electron. J. Biotechnol. 16, 1-9.

Silva, L.A.O., Terrasan, C.R.F., Carmona, E.C., 2015. Purification and characterization of xylanases from Trichoderma inhamatum. Electron. J. Biotechnol. 18, 307-313.

Silva, V.C.T., Coto, A.L.S., Souza, R.C., Neves, M.B.S., Gomes, E., Bonilla-Rodriguez, G.O., 2016. Effect of $\mathrm{pH}$, temperature, and chemicals on the endoglucanases and $\beta$ Glucosidases from the thermophilic fungus Myceliophthora heterothallica F. 2. 1.4. obtained by solid-state and submerged cultivation. Biochem. Res. Int. 1-9.

Soni, S.K., Soni, R., 2010. Regulation of celulase synteshis in Chaetomium erraticum. BioResources 5, 81-98.

Souza, F.H.M., Nascimento, C.V., Rosa, J.C., Masui, D.C., Leone, F.A., Jorge, J.A., Furriel, R.P.M., 2010. Purification and biochemical characterization of a mycelial glucoseand xylose-stimulated $\beta$-glucosidase from the thermophilic fungus Humicola insolens. Process. Biochem. 45, 272-278.

Sun, Y., Cheng, J., 2002. Hydrolysis of lignocellulosic materials for ethanol production: a review. Bioresour. Technol. 83, 1-11.

Terrasan, C.R., Temer, B., Duarte, M.C., Carmona, E.C., 2010. Production of xylanolytic enzymes from Peniciullium janczewskii. Bioresour. Technol. 101, 4139-4143.

Villena, M.A., Iranzo, J.F.U., Gundllapalli, S.B., Otero, R.R.C., Pérez, A.I.B., 2006. Characterization of an exocellular $\beta$-glucosidase from Debaryomyces pseudopolymorphus. Enzyme Microb. Technol. 39, 229-234.

Xin, F., Geng, A., 2010. Horticultural waste as the substrate for cellulase and hemicellulase production by Trichoderma reesei under solid-state fermentation. Appl. Biochem. Biotechnol. 162, 295-306.

Yan, Q.J., Wang, L., Jiang, Z.Q., Yang, S.Q., Zhu, H.F., Li, L.T., 2008. A xylose-tolerant $\beta$ xylosidase from Paecilomyces thermophila: characterization and its co-action with the endogenous xylanase. Bioresour. Technol. 99, 5402-5410.

Zanoelo, F.F., Polizeli, M.L.T.M., Terenzi, H.F., Jorge, J.A., 2004. $\beta$-Glucosidase activity from the thermophilic fungus Scytalidium thermophilum is stimulated by glucose and xylose. FEMS Microbiol. Immunol. 240, 137-143.

Zimbardi, A.L.R.L., Sehn, C., Meleiro, L.P., Souza, F.H.M., Masui, D.C., Nozawa, M.S.F., Guimarães, L.H.S., Jorge, J.A., Furriel, R.P.M., 2013. Optimization of $\beta$-Glucosidase, $\beta$-Xylosidase and xylanase production by Colletotrichum graminicola under solid-state fermentation and application in raw sugarcane trash saccharification. Int. J. Mol. Sci. 14, 2875-2902. 